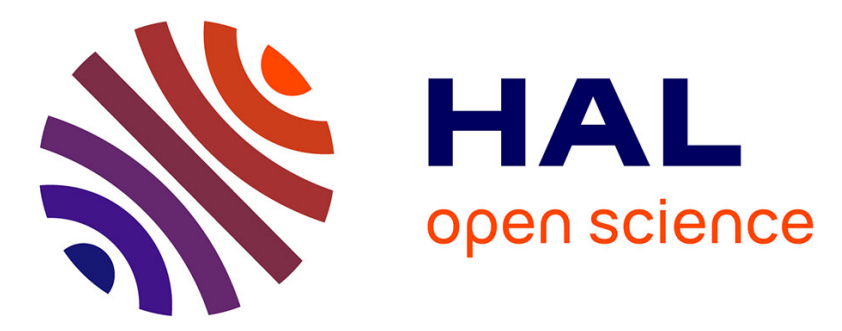

\title{
Permian-Triassic amalgamation of Asia: Insights from Northeast China sutures and their place in the final collision of North China and Siberia
}

Wei Lin, Michel Faure, Sébastien Nomade, Qinghua Shang, Paul Randall

Renne

\section{To cite this version:}

Wei Lin, Michel Faure, Sébastien Nomade, Qinghua Shang, Paul Randall Renne. Permian-Triassic amalgamation of Asia: Insights from Northeast China sutures and their place in the final collision of North China and Siberia. Comptes Rendus Géoscience, 2008, 340 (2-3), pp.190-201. 10.1016/j.crte.2007.10.008 . insu-00191503

\section{HAL Id: insu-00191503 \\ https://hal-insu.archives-ouvertes.fr/insu-00191503}

Submitted on 27 Mar 2008

HAL is a multi-disciplinary open access archive for the deposit and dissemination of scientific research documents, whether they are published or not. The documents may come from teaching and research institutions in France or abroad, or from public or private research centers.
L'archive ouverte pluridisciplinaire HAL, est destinée au dépôt et à la diffusion de documents scientifiques de niveau recherche, publiés ou non, émanant des établissements d'enseignement et de recherche français ou étrangers, des laboratoires publics ou privés. 


\title{
Permian-Triassic amalgamation of Asia: Insights from Northeast China sutures and their place in the final collision of North China and Siberia \\ L'amalgamation permo-triasique de l'Asie : données nouvelles sur les sutures en Chine du Nord-Est et leur place dans la collision finale de la Chine du Nord avec la Sibérie
}

\author{
Wei Lin $^{\mathrm{a}}$, Michel Faure ${ }^{\mathrm{b}}$, Sébastien Nomade ${ }^{\mathrm{c}, \mathrm{d}, \mathrm{e}}$, Qinghua Shang ${ }^{\mathrm{f}}$ and Paul Randall \\ Renne $^{c, d}$
}

${ }^{a}$ State Key Laboratory of Lithospheric Evolution, Institute of Geology and Geophysics, Chinese Academy of Sciences, Beijing 100029, China

bUMR 6113, institut des sciences de la Terre d'Orléans, université d'Orléans, CNRS/INSU, 45067 Orléans cedex 2, France

${ }^{\mathrm{c} B e r k e l e y ~ G e o c h r o n o l o g y}$ Center, 2455 Ridge Road, Berkeley, CA 94709, USA

${ }^{\mathrm{d}}$ Department of Earth and Planetary Science, University of California, Berkeley, CA 94720, USA

${ }^{\mathrm{e}}$ Laboratoire des sciences du climat et de l'environnement, CEA-CNRS-UVSQ, IPSL, avenue de la Terrasse, 91190 Gif-sur-Yvette cedex, France

Institute of Vertebrate Paleontology and Paleoanthropology, Chinese Academy of Science, Beijing 100044, China

\begin{abstract}
The Central Asia Orogenic Belt (CAOB) corresponds to the domain where Siberia and Mongolia were welded to North China. The eastern extension of the CAOB in Northeast China is disputed, since both suture location and timing are poorly documented. This paper reports for the first time the recognition of two suture zones in the southern part of Northeast China (Manchuria), between the Fushun Mishan and Yilan-Yitong faults. In the Jilin Province, west-directed thrust sheets involving successively, from west to east, passive continental margin rocks, metamorphic rocks and ophiolites, block-in-matrix formations and arc plutons indicate a Permian-Early Triassic collision. In the Liaoning Province, arc plutonism and top-to-the-north ductile shearing, coeval with the emplacement of an ophiolitic nappe, suggest a Palaeozoic collision. These two sutures are correlated with the Ondor Sum and Solonker sutures, described in Inner Mongolia. A new geodynamic model involving rifting and collision of the southern part of the Xilinhot Block with North China is proposed.
\end{abstract}

\section{Résumé}

La ceinture plissée d'Asie centrale (CAOB) correspond au domaine dans lequel la Sibérie et la Mongolie se sont soudées à la Chine du Nord. L'extension orientale de ce domaine est discutée, car la localisation des sutures et la chronologie sont mal connues. Dans la partie sud de la Chine du Nord-Est (Mandchourie méridionale), entre les failles de Fushun-Mishan et de Yilan-Yitong, deux sutures sont reconnues pour la première fois. Dans la province de Jilin, des chevauchements vers l'ouest impliquent successivement, d'ouest en est, des roches de marge continentale passive, des roches métamorphiques et des ophiolites, une série à blocs et des plutons d'arcs. Cette architecture s'accorde avec une collision d'âge Permien supérieur à Trias inférieur. Dans la province de Liaoning, des plutons d'arc et une série ophiolitique 
déformée ductilement par des cisaillements vers le nord suggèrent une collision d'âge Carbonifère. Ces deux sutures sont corrélées avec celles d'Ondor Sum et de Solonker, en Mongolie intérieure. Un modèle géodynamique impliquant deux subductions océaniques entre les blocs continentaux de Chine du Nord et de Xilinhot est proposé pour rendre compte de la formation de la terminaison orientale de la CAOB.

Keywords: NE China; Suture zones; Continental collision; Central Asia Orogenic Belt; Indosinian tectonics

Mots clés: Chine du Nord-Est; Sutures; Collision continentale; Ceinture plissée d'Asie centrale; Tectonique indosinienne

\section{Introduction}

It is now widely accepted that Eurasia was built up during Palaeozoic times by successive accretions and collisions of intraoceanic arcs and continental microblocks around the Siberian craton. Along the southern margin of Siberia, the Central Asia Orogenic Belt (CAOB), extending from Kazakhstan to the Pacific Ocean corresponds to places where the southern continents of Tarim and North China, and several microcontinents of Mongolia were successively welded to Siberia. The northern and southern parts of the CAOB are referred to the Altaids and the Manchurides, respectively (e.g., [16], [17] and [26]). The latter develops in Inner Mongolia and corresponds to a 300-km-wide east-west-trending belt that separates Mongolian arcs developed along the southern margin of Siberia and microcontinents and magmatic arcs belonging to the North China Block [9], [17] and [32]. Eastward, the CAOB is overprinted by the Cretaceous-Eocene, NE-SW-trending Songliao rift. More to the east, the Mandchurides interfere with the orogens related to the Pacific margin of Eurasia, ranging from Sikhote Alin to Japan (e.g., [3] and [12]).

Due to poor outcrop conditions and restricted access until recently, little information is available about the eastern part of CAOB. This paper provides first-hand results based on field surveys and laboratory analyses on the Late Palaeozoic to Early Mesozoic sutures located between the Yilan-Yitong and Fushun-Mishan faults in the Jilin and Liaoning Provinces of Northeast China (Fig. 1). A possible correlation with ophiolites, accretionary complexes, and magmatic arcs of Inner Mongolia is discussed, and a tentative geodynamic evolution model is proposed.

\section{The Permian-Early Triassic suture in the Central Jilin Province}

\subsection{Bulk architecture of the belt}

In the Central Jilin Province, four litho-tectonic domains are recognized from west to east. They allow us to reconstruct the architecture of a convergent plate boundary (Fig. 1). To the west, the Late Palaeozoic series consists of shallow-water continental shelf deposits [6]. Cambrian and Ordovician limestone and argillite are overlain by Carboniferous and Permian limestone, sandstone, and shale.

Eastward, the second domain is characterized by metamorphic rocks (Hulan Group) and a mafic-ultramafic association (Hongqiling Group) [6], [29] and [31]. The upper greenschist to amphibolite facies metamorphic rocks, namely biotite-garnet \pm kyanite micaschists, quartzites, marbles and amphibolites enclose gabbro, diabase, serpentinite, ultramafic rocks, some of which contain economic $\mathrm{Ni}-\mathrm{Cu}$ concentrations [30] and [32]. Although previously 
considered as post-orogenic intrusions (e.g., [28] and [35]), our structural observations show that these ultramafic bodies are underlain by amphibolites. As a whole, we interpret this mafic-ultramafic association as an ophiolitic suite surrounded by metamorphic rocks. Based on LA-ICP-MS dating of detrital zircons enclosed in the metapelites, an Early Permian age (ca. $290 \mathrm{Ma}$ ) is inferred for the age of the metamorphic rocks. Micaschists yield Rb-Sr wholerock-muscovite-biotite ages of $233 \pm 8 \mathrm{Ma}$ and $253 \pm 10 \mathrm{Ma}$, interpreted as that of the syntectonic metamorphism [29].

To the east, the sedimentary rocks assigned to the Permian exhibit typical features of a blockin-matrix formation. Well-bedded turbidite, lenticular masses of coarse-grain sandstone, slump deposit, and pebbly mudstone are common facies (Fig. 2). Blocks of various lithologies such as chert, serpentinite, acidic tuff, andesitic and basaltic breccia, with sizes ranging from the millimetre to the kilometre scale, are widespread in this chaotic formation. Carboniferous and Permian limestones form metre- to kilometre-size blocks included into the terrigenous matrix. The above-mentioned rocks are olistoliths deposited in a terrigenous matrix, and subsequently sheared. Based on the foraminifera found in limestone, the age of this chaotic formation is considered as Permian [21]. However, since limestones are blocks, the real age of the matrix remains unsettled yet, but it cannot be younger than the Late Triassic, which is the age of the terrestrial shallow-water conglomerate and sandstone that unconformably cover the chaotic formation [6] (Fig. 1). Therefore, a Late Permian-Early Triassic age for this mélange is proposed here. More to the east, but isolated from the previous domains by Late Mesozoic continental red beds and granitic plutons, several calc-alkaline plutons of gabbro, diorite and tonalite intrude into a metamorphic series developing a contact metamorphism. All these units are intruded by Jurassic quartz-diorite plutons [29].

These field observations led us to propose the following bulk architecture (Fig. 1). The Late Palaeozoic western sedimentary unit represents the passive continental margin of a western continental block. The mafic-ultramafic suite corresponds to a synmetamorphic, ductilely deformed, Permian ophiolitic series, tectonically inserted in metamorphic rocks. The metamorphic rocks and the ophiolitic series overthrust from east to west the continental margin series. The bloc-in-matrix series is interpreted as an accretionary complex formed in an active continental margin. Finally, to the east, the calc-alkaline dioritic-tonalitic plutonic rocks are the deep parts of a pre-Jurassic magmatic arc, emplaced in an eastern continental basement.

\subsection{Structural outline}

In spite of discontinuous exposures, a deformation gradient, increasing from west to east, can be documented (Fig. 1). The eastward-dipping formations are involved into a west-directed thrust system, locally refolded by kilometre-scale upright folds. In the western area, the ductile deformation is absent, but numerous brittle thrust faults or en-échelon tension gashes indicate a top-to-the-west displacement (Fig. 2). In the metamorphic rocks (Hulan group, e.g., [29]), the flat-lying mylonitic foliation contains an east-west-trending mineral and stretching lineation. In marbles, metre-scale marble boudins, also stretched in the east-west direction, are well developed (Fig. 1). The mafic rocks are often transformed into well-foliated and lineated amphibolites. Along the east-west-trending lineation, whatever the lithology, ductile shear criteria indicate a top-to-the-west motion. West-directed shearing is observed in the chaotic formation too. The block rims are foliated, and in the slaty mudstone matrix, pebbles are boudinated. Conversely, in the arc domain, the metamorphic rocks exhibit a north-southtrending lineation that is unrelated to this thrusting event since the plutons are not deformed (Fig. 1). 


\subsection{Chronological constraints}

In the study area, stratigraphic and radiometric dates remain rare. Therefore, $a{ }^{40} \mathrm{Ar} /{ }^{39} \mathrm{Ar}$ study has been undertaken in order to assess the age of the synmetamorphic shearing. Samples, located in Fig. 1, are amphibolite from the base of the ophiolitic nappe: JL11, 12; marble: JL 17; and diorite from the magmatic arc: JL 28, JL 30.

\subsection{Analytical method}

Hornblende (JL 11, JL12, JL28, JL30: 450 to $350 \mathrm{~m}$ ), biotite (JL28: 450 to $350 \mathrm{~m}$ ) and muscovite (JL17: 450 to $350 \mathrm{~m}$ ) were concentrated using a Frantz magnetic separator and a vibration table. Several grains free of alteration were selected under the binocular for each sample. Ten to fifteen grains for each mineral phase were loaded in an Al disk and irradiated for $12 \mathrm{~h}$ in the CLICIT facility of the TRIGA reactor at the Oregon State University. After irradiation, single grains are degassed with a defocused $\mathrm{CO}_{2}$ Synrad ${ }^{\mathcal{O}}$ laser, then analyzed with a MAP 215C mass spectrometer using the methods described by Renne et al. [15]. Neutron fluence $(J)$ was monitored by a Fish Canyon sanidine (FCS: $28.02 \mathrm{Ma}$ ) loaded in the same disks. The $J$ value $(0.003103 \pm 0.000007)$ is determined from individual analyses of six separate FCS grains fused with the $\mathrm{CO}_{2}$ laser and is calculated with the total decay constant of Steiger and Jäger [22]. Mass discrimination, monitored by automated analysis of air pipettes, was $1.00374 \pm 0.000248(n=28 ; 2 \sigma$ error $)$ per mass atomic unit. Nucleogenic production ratios from $\mathrm{K}$ and $\mathrm{Ca}$ were $\left({ }^{40} \mathrm{Ar} /{ }^{39} \mathrm{Ar}\right)_{\mathrm{K}}=(7.3 \pm 0.9) \times 10^{-4}$, $\left({ }^{39} \mathrm{Ar} /{ }^{37} \mathrm{Ar}\right)_{\mathrm{Ca}}=(7.60 \pm 0.09) \times 10^{-4}$ and $\left({ }^{36} \mathrm{Ar} /{ }^{37} \mathrm{Ar}\right)_{\mathrm{Ca}}=(2.70 \pm 0.02) \times 10^{-4}(2 \sigma$ error $)$. Plateau ages are defined as comprising three continuous steps corresponding to a least $70 \%$ of the total ${ }^{39} \mathrm{Ar}$ released. The individual fraction ages should agree within $2 \sigma$ with the integrated age of the plateau segment.

\subsection{Results}

All uncertainties are given at $2 \sigma(95 \%$ confidence). The biotite single-grain spectrum (JL28, Fig. 3) is slightly discordant, the first $15-20 \%$ of the spectrum displaying younger apparent ages. The plateau defined by $78 \%$ of the total ${ }^{39} \mathrm{Ar}$ yields an age of $187.0 \pm 0.6 \mathrm{Ma}$. Such a weakly discordant behaviour can be explained by the spurious presence of chlorite interlayer or a partial loss of ${ }^{40} \mathrm{Ar}$ in the outer part of the crystal [13]. Muscovite (JL 17, Fig. 2) displays a flat spectrum with a plateau age of $187.9 \pm 1.2 \mathrm{Ma}\left(100 \%\right.$ of $\left.{ }^{39} \mathrm{Ar}\right)$. Hornblende spectra (JL11, JL12, JL28, JL 30, Fig. 2) are also flat, with young apparent ages at low temperatures (first $10-20 \%$ of total ${ }^{39} \mathrm{Ar}$ ). These young age steps, positively correlated with lower $\mathrm{Ca} / \mathrm{K}$ ratios, suggest that the K-rich alteration phase degassed early in the experiment. The plateau age of ca 190 Ma obtained on hornblende JL 28 is slightly older than the one of $187 \mathrm{Ma}$, obtained on the biotite from the same sample, suggesting a fast cooling.

\subsection{Discussion of the age significance}

The Late Triassic unconformity recognized in the field implies that the metamorphic rocks cannot be younger than $225 \mathrm{Ma}$, according to the time scale [4]. Even the older dates of 218 and $208 \mathrm{Ma}$ for hornblende in the amphibolites JL 11, JL 12 do not comply with this constraint. Furthermore, muscovite from marble (JL 17) and biotite and amphibole from the diorites (JL 28, JL 30) yield radiometric ages around 190 Ma, that is, Early Jurassic. Such a discrepancy can be explained by a complete thermal reset of the $\mathrm{K}$-Ar system during the emplacement of the Jurassic granites [29], whereas it suggests excess temperatures of 500$550{ }^{\circ} \mathrm{C}$. The numerous Mesozoic plutons that crop out in the area might be also responsible for fluid circulation and recrystallization of the host rocks, as well as for the opening of the 
$\mathrm{K}-\mathrm{Ar}$ chronometer. Another possibility will be a ${ }^{40} \mathrm{Ar}$ loss during deformation [11]; however, this hypothesis is less probable. It is worth noting that our results are close to the 216-217-Ma $\mathrm{Rb} / \mathrm{Sr}$ age yielded by biotite micaschist [29]. Moreover, the ${ }^{40} \mathrm{Ar} /{ }^{39} \mathrm{Ar}$ ages of ca $225 \mathrm{Ma}$ from biotite and muscovite obtained in the micaschist associated with the mafic-ultramafic rocks comply with an Early Triassic age for the thrusting [30]. South of the Fushun-Mishan fault (Fig. 2), calc-alkaline metavolcanites similar to those of the above-described magmatic arc yield $260 \pm 2$-Ma zircon SHRIMP ages that are interpreted as the age of the magmatism, in good agreement with our own conclusion. Finally, sericite from the hydrothermalized goldbearing vein yields a ${ }^{40} \mathrm{Ar} /{ }^{39} \mathrm{Ar}$ age of $204 \pm 0.5 \mathrm{Ma}$, which suggests an important Late Triassic magmatic episode associated with a hydrothermal event [10].

These new petrological, structural, and geochronological data of the Jilin area allow us to propose that the study area is a suture zone separating two continental blocks. The eastward dip of the subduction is deduced from the magmatic arc in the eastern block (Fig. 1). The blocky formation is the accretionary complex developed in the subduction zone. The ophiolite nappe was transported westward in metamorphic conditions during the Late Permian-Early Triassic collision. As discussed below, the western and eastern blocks can be respectively correlated with the northeastern part of the NCB (here named Liaoji) and Xilinhot Blocks, which are recognized in the western part of the CAOB (e.g., [17] and [32]).

\section{The Palaeozoic suture in the Liaoning Province}

Southwest of the Permian-Triassic Jilin suture, in the Tieling area of the North Liaoning Province, between the Yilan-Yitong (northern segment of Tanlu fault) and the Fushun-Mishan faults, two contrasted tectonic zones crop-out and allow us to recognize another suture of the Palaeozoic (Fig. 4). The southern zone consists of Palaeoproterozoic gneiss and migmatites, unconformably covered by Meso- to Neoproterozoic rocks, Late Permian sandstone, and Jurassic to Cretaceous red beds. The Proterozoic sequence is intruded by Palaeozoic dioritic plutons [5] and [6]. Our geochemical analyses indicate a calc-alkaline character for these plutons.

The northern zone consists of metapelite, cherts, rare limestones, gabbroic sandstone, and breccia of gabbro, basalt, and chert (Fig. 5). All these metasediments experienced a greenschist- to amphibolite- facies metamorphism. Several metre- to kilometre-scale masses of mylonitic gabbro crop out within sheared metapelites. As a whole, this rock assemblage corresponds to a dismembered ophiolitic sequence. The southern zone is weakly deformed by broad upright folds. Conversely, the northern zone experienced an intense ductile shearing older than the Late Carboniferous plutons that intrude the metamorphic rocks. The flat-lying or southward gently dipping foliation contains a north-south- to NW-SE-trending mineral and stretching lineation. Kinematic indicators, such as sigma-type porphyroclast systems, pressure shadows and shear bands indicate a top-to-the-north ductile shearing (Fig. 5). Along the tectonic boundary between the northern and southern zones, the subvertical foliation and the sub-horizontal lineation suggest that wrenching has reworked the primary flat-lying contact.

The structural data, petrological assemblage, and tectonic setting lead us to interpret the Tieling area as a Palaeozoic suture. The southern calc-alkaline plutons form the deep part of a magmatic arc developed in the upper plate, and the foliated mafic and metasedimentary rocks form an ophiolitic nappe transported to the north, but the autochthonous is presently hidden by the granitic plutons (Fig. 4). In spite of a lack of radiometric dates, a Palaeozoic age would comply with the occurrences of undeformed Permian deposits of the southern zone.

Conversely to the Jilin suture, an accretionary complex and a fore-arc basin are missing in the 
Liaoning suture. A possible explanation would be that these elements disappeared by strikeslip shearing along the suture zone. In fact, the subvertical foliation attitude in the suture zone complies with this interpretation.

\section{The Northeast China sutures within the CAOB framework}

In order to be interpreted in terms of geodynamics, the two suture zones of Northeast China defined here must be correlated with similar structures of the western part of the CAOB, in Inner Mongolia. There, several magmatic arcs, ophiolitic belts, and accretionary complexes are recognized, but due to poor outcrop conditions, the direction of subduction and the timing of accretion and collision remain disputed (e.g., [2], [9], [17], [19], [23], [24], [32] and [33]). The Inner Mongolian suture zones are often referred to as the 'Solonker multiple suture'; however, this terminology mainly reflects our poor understanding of this area. This $200-\mathrm{km}-$ wide domain can be subdivided into several distinct belts (Fig. 6). The northernmost Devonian to Carboniferous Hegenshan suture extends northeastwards below the CretaceousEocene Songliao rift; therefore, it cannot be correlated with the Jilin and Liaoning sutures described in this paper.

More to the south, two suture zones are recognized in Inner Mongolia. Along the northern border of the North China Block (NCB), the Palaeozoic Bainaimiao magmatic arc and the Ondor Sum accretionary complex, including Early-Middle Palaeozoic HP rocks and ophiolites, developed in response to a south-directed subduction (e.g., [33] and [34]; Fig. 6). Northeast of Beijing, a Carboniferous magmatic arc, installed upon the Palaeo-Proterozoic basement of NCB, attests to a south-directed subduction [36] and [37]. This tectonic pattern might agree with our data on the Liaoning suture, since kinematic indicators support a top-tothe-north shearing of the ophiolitic nappe. In both Inner Mongolia and Liaoning, the nature of the crust that underlies the Ondor Sum complex is unknown. In Northeast China, this continental basement might correspond to the southern part of the Jiamusi Block (Fig. 6A); however, this correlation rises some difficulties for the correlation with the Jilin suture, which is not represented in Fig. 6A [17].

In Inner Mongolia, the Carboniferous-Permian Baolidao magmatic arc formed in response to a north-directed subduction [32] (Fig. 6B). The Erdaojing accretion complex that contains Permian ophiolite, cherts, and turbidites [18] can be compared to the Jilin accretionary complex (Fig. 6), both from structural and chronological aspects. The Baolidao Arc of Inner Mongolia seems to be underlain by a gneissic Proterozoic substratum [1], [23] and [32], called the Xilinhot Block; such a correlation is considered in Fig. 6B.

To the east of the Fushun-Mishan fault, the Jilin suture extends to the Yanji area [7], [20], [27] and [28] and also in North Korea [14] (Fig. 6B). According to [17], the Jilin suture, north of the Fushun-Mishan fault, is unrelated with the Mongolian sutures, but is relevant to the Pacific margin of eastern Eurasia (Fig. 6A). Through this suture, the Khanka Block became welded to the Liaoji Block that belongs to the NCB. However, this interpretation does not take into account the extension of the Jilin suture north of the Fushun-Mishan fault, as described here. In agreement with Jia et al. [7], another view is preferred here. The Khanka and Jiamusi Blocks belong to a single microcontinent that collided with Asia in Early Palaeozoic times [25] along the Mudanjiang suture. However, in the present state of knowledge, the detailed relative evolutions of the Khanka-Jiamusi Block and of the Xilinhot Block are unsettled yet. The relationships between the Xilinhot, Khanka and Jiamusi Blocks remain highly speculative.

The above-presented data allow us to correlate the suture zones of Northeast China with those described in Inner Mongolia, and to propose a geodynamic scenario for the formation of the 
south part of the CAOB, involving two successive accretion-collision events (Fig. 7). In the Early Palaeozoic, a southward subduction below the NCB led to the collision of a continental stripe along the Ondor Sum-Liaoning suture. As stated above, the underlying continental block is unknown. One possibility would be that this microcontinent was a rifted part of the Xilinhot Block; however, an independent microcontinent is also possible. In the Late Permian-Early Triassic, the Xilinhot Block, which was already welded to Siberia along the Hegenshan suture, collided with the North China Block after a north-directed subduction forming the Solonker-Jilin suture. As a result, the amalgamation of East Asia along the CAOB was completed in the Late Triassic.

\section{Acknowledgements}

Field and laboratory expenses have been supported by NSFC projects (40202021, 40472116) and the Association franco-chinoise pour la recherche scientifique et technique (grant PRA T01-03). BGC is also acknowledged for granting access to the Ar/Ar lab. J. Charvet is thanked for his suggestions to improve the first draft of this paper. B. Xu and W. Xiao are thanked for their constructive remarks.

\section{References}

[1] G. Badarch, W.D. Cunningham and B. Windley, A new terrane subdivision for Mongolia: implications for the Phanerozoic crustal growth of Central Asia, J. Asian Earth Sci. 21 (2002), pp. 87-110.

[2] C. Cao, The ophiolite belts of northeastern China, J. Southeast Asian Earth Sci. 3 (1989), pp. 233-236.

[3] M. Faure and B. Natal'in, The geodynamic evolution of the eastern Eurasian margin in Mesozoic times, Tectonophysics 208 (1992), pp. 397-411.

[4] F. Gradstein, J. Ogg, A. Smith, W. Bleeker and L. Lourens, A new geologic Time scale with special reference to Precambrian and Neogene, Episodes 27 (2004), pp. 83-100.

[5] Y. Huan, S. Pei, S. Chen, Z. Hong and G. Zhao, Ophiolitic mélanges in the Kaiyuan group, Reg. Geol. China 18 (1999), pp. 248-255.

[6] JBGMB (Jilin Bureau of Geology and Mineral Resources), Regional Geology of Jilin Province, Geol. Memoirs, 10, Geol. Publishing House, Beijing, China, 1989.

[7] D. Jia, R. Hu, Y. Lu and X. Qiu, Collision between the Khanka block and the North China block in the Yanbian Region, Northeast China, J. Asian Earth Sci. 23 (2004), pp. 211-219.

[8] LBGMR (Liaoning Bureau of Geology and Mineral Resources), Regional Geology of Liaoning Province, Geol. Memoirs, 14, Geol. Publishing House, Beijing, China, 1989.

[9] J.Y. Li, Permian geodynamic setting of Northeast China and adjacent regions: closure of the Paleo-Asian Ocean and subduction of the Paleo-Pacific Plate, J. Asian Earth Sci. 26 (2006), pp. 207-224 
[10] L. Miao, Y. Qiu, W. Fan, F. Zhang and M. Zhai, Geology, geochronology, and tectonic setting of the Jiapingou gold deposits, southern Jilin Province, China, Ore Geol. Rev. 26 (2005), pp. 137-165.

[11] M. Mulch and M. Cosca, Recrystallization or cooling age: in situ laser ${ }^{40} \mathrm{Ar} /{ }^{39} \mathrm{Ar}$ geochronology of muscovite in mylonitic rocks, J. Geol. Soc. 161 (2004), pp. 573-582.

[12] B. Natal'in, L. Parfenov, A. Vrublevsky, L. Karakov and V. Yushmanov, Main fault systems of the Soviet Far East, Philos. Trans. R. Soc. Lond. 317 (1986), pp. 267-275.

[13] S. Nomade, P.R. Renne and R.K.W. Merkle, ${ }^{40} \mathrm{Ar} /{ }^{39} \mathrm{Ar}$ age constraints on ore deposition and cooling of the Bushweld Complex, S. Africa, J. Geol. Soc. 161 (2004), pp. 411-420.

[14] R.J. Paek, R.G. Kan, G.P. Jon, Y.M. Kim and Y.H. Kim, Geology of Korea, Geological Institute, Academy of Sciences, DPR of Korea, Pyongyang (1993).

[15] P.R. Renne, C.C. Swisher, A.L. Deino, D.K. Karner, T.L. Owens and D.J. DePaolo, Intercalibration of standards, absolute ages and uncertainties in ${ }^{40} \mathrm{Ar} /{ }^{39} \mathrm{Ar}$ dating, Chem. Geol. 145 (1998), pp. 117-152.

[16] A.M.C. Sengör, B.A. Natal'in and V.S. Burtman, Evolution of the Altaid tectonic collage and Palaezoic crustal growth of Eurasia, Nature 364 (1993), pp. 299-307.

[17] A.M.C. Sengör and B.A. Natal'in, Paleotectonics of Asia: fragments of a synthesis. In: A. Y in and T.M. Harrison, Editors, Tectonic Evolution of Asia, Cambridge University Press, Cambridge, UK (1996), pp. 486-640.

[18] Q. Shang, Occurrences of Permian Radiolarians in central and eastern Neimongol (Inner Mongolia) and their geological significance for the North China Orogen, Chin. Sci. Bull. 49 (2004), pp. 2613-2619.

[19] J.A. Shao, Continental crust accretion and tectono-magmatic activity at the northern margin of the Sino-Korean plate, J. Southeast Asian Earth Sci. 3 (1989), pp. 57-62.

[20] J.A. Shao and K.D. Tang, The ophiolite mélange in Kaishantun, Jilin province, China, Acta Petrol. Sin. 11 (1995), pp. 212-220.

[21] S.Z. Shen, H. Zhang, Q.H. Shang and W.Z. Li, Permian stratigraphy and correlation of Northeast China: a review, J. Asian Earth Sci. 26 (2006), pp. 304-326.

[22] R.H. Steiger and E. Jäger, Subcommission on geochronology: convention on the use of decay constants in geo- and cosmochronology, Earth Planet. Sci. Lett. 36 (1977), pp. 359362.

[23] K. Tang, Tectonic development of Paleozoic fold belts at the northern margin of the Sino-Korea craton, Tectonics 9 (1990), pp. 249-260.

[24] Q. Wang and X. Liu, Paleoplate Tectonics between Cathaysian and Angaraland in Inner Mongolia of China, Tectonics 5 (1986), pp. 1073-1088. 
[25] S. Wilde, X. Zhang and F. Wu, Extension of a newly-identified 500 Ma metamorphic terrain in NE China: further U-Pb SHRIMP dating of the Mashan Complex, Heilongjiang Province, Tectonophysics 328 (2000), pp. 115-130.

[26] B. Windley, D. Alexeiev, W. Xiao, A. Kröner and G. Badarch, Tectonic models for accretion of the Central Asian Orogenic Belt, J. Geol. Soc. 164 (2007), pp. 31-47.

[27] H. Wu, K. Tang and C. Li, The assemblage chloritoid + carpholite + phengite in lowgrade metamorphic rocks in Kaishantun area, Yanbian, Jilin Province, Geol. Bull. China 22 (2003), pp. 651-654.

[28] F. Wu, S. Wilde, G. Zhang and D. Sun, Geochronology and petrogenesis of the postorogenic $\mathrm{Cu}-\mathrm{Ni}$ sulfide-bearing mafic-ultramafic complexes in Jilin Province, NE China, $J$. Asian Earth Sci. 23 (2004), pp. 781-797.

[29] F. Wu, G. Zhao, D. Sun, S. Wilde and J. Yang, The Hulan group: its role in the evolution of the Central Asian orogenic belt of NE China, J. Asian Earth Sci. 30 (2007), pp. 542-556.

[30] A. Xi, H. Ren, B. Zhang, Y. Wang, S. Shi and H. Zhi, Isotopic chronology of the Hulan group and its geological significance in the central Jilin Province, J. Jilin Univ. 33 (2003), pp. $15-18$.

[31] A. Xi, L. Gu, X. Li and Y. Zheng, The Magmatic Sulphide Cu-Ni Deposits and Their Earth Dynamics Setting in North Orogenic Belt of China: A Case Study of Hongqiling Deposits, Acta Geol. Sin. 80 (2006), pp. 1721-1729

[32] W. Xiao, B.F. Windley, J. Hao and M. Zhai, Accretion leading to collision and the Permian Solonker suture, Inner Mongolia, China: Termination of the Central Asian orogenic belt, Tectonics 22 (2003), p. 1069.

[33] B. Xu and B. Chen, Framework and evolution of the Middle Paleozoic orogenic belt between Siberia and North China Plates in northern Inner Mongolia, Sci. China 40 (1997), pp. 463-469.

[34] B. Xu, J. Charvet and F. Zhang, Primary study on petrology and geochronology of blueschists in Sunitezhuoqi, northern Inner Mongolia, Chin. J. Geol. 36 (2001), pp. 424-434.

[35] G. Zhang and F. Wu, Geochronology significances of the post-orogenic mafic-ultramafic rocks in Hongqiling area of Jilin Province, NE China, Seismol. Geol. 27 (2005), pp. 600-608.

[36] S. Zhang, Y. Zhao, B. Song and H. Wu, The Late Paleozoic gneissic granodiorite pluton in Early Pre-Cambrian high-grade metamorphic terrains near Longhua County in northern Hebei province, North China: result from zircon SHRIMP U-Pb dating and its tectonic implications, Acta Petrol. Sin. 20 (2004), pp. 621-626.

[37] Y. Zhang, F. Wu, S. Wilde, M. Zhai, X. Lu and D. Sun, Zircon U-Pb ages and tectonic implications of Early Paleozoic granitoids at Yanbian, Jilin Province, Northeast China, The Island Arc 13 (2004), pp. 484-505 


\section{Figures}

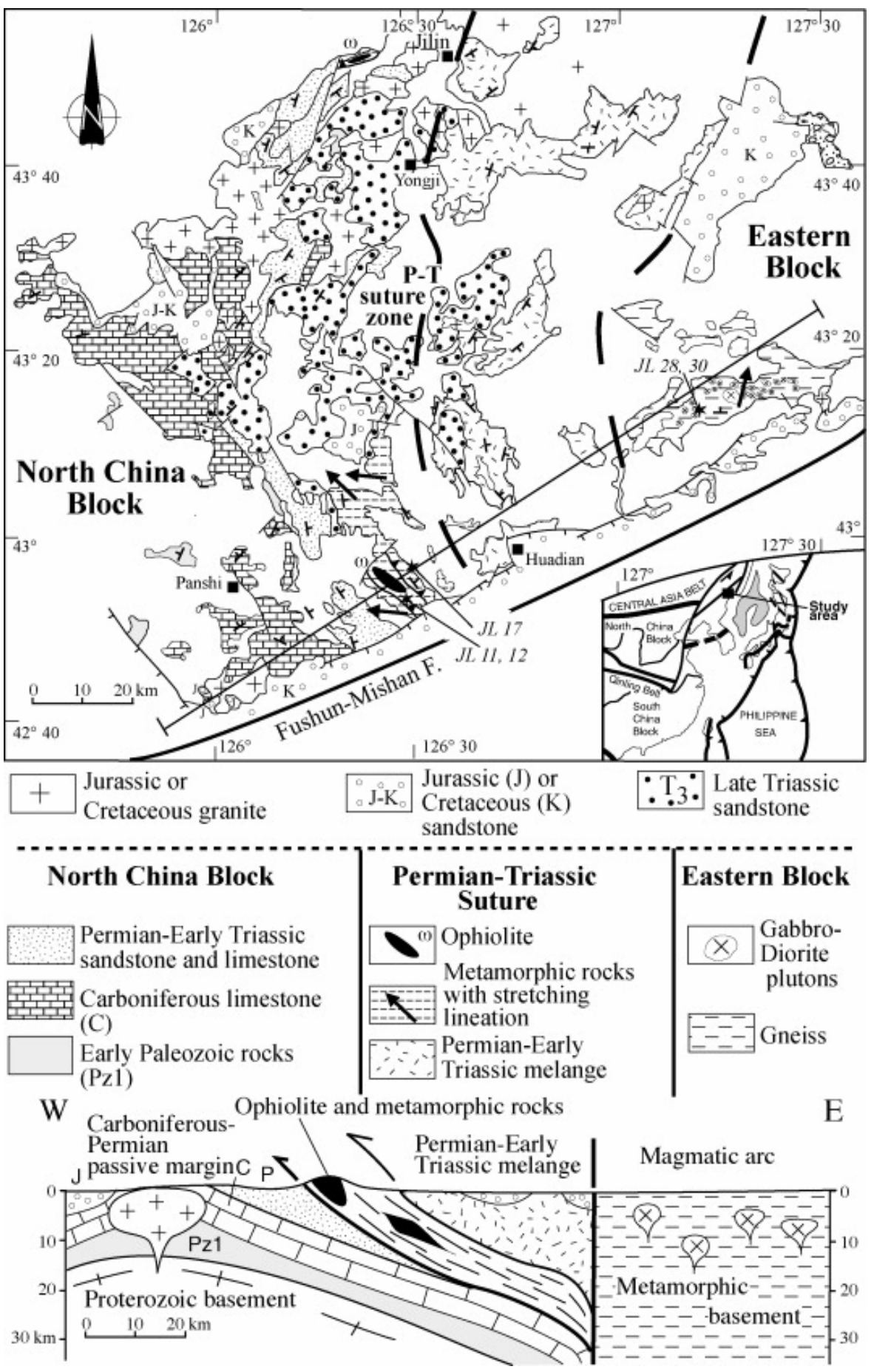

Fig. 1. Structural map and cross section of the Jilin area adapted from [6] and upgraded by personal data. YYF: Yilan-Yitong fault, FMF: Fushun-Mishan fault, CAOB: Central Asia Orogenic Belt. Stars locate the samples analyzed for ${ }^{40} \mathrm{Ar} r^{39} \mathrm{Ar}$ radiometric dating shown in Fig. 3.

Fig. 1. Schéma structural et coupe de la région de Jilin, modifiés d'après [6] et complétés par nos données personnelles. YYF : faille Yilan-Yitong, FMF : faille Fushun-Mishan, CAOB: ceinture orogénique d'Asie centrale. Les étoiles indiquent la situation des échantillons datés par la méthode ${ }^{40} \mathrm{Ar}{ }^{39} \mathrm{Ar}$, et présentés sur la Fig. 


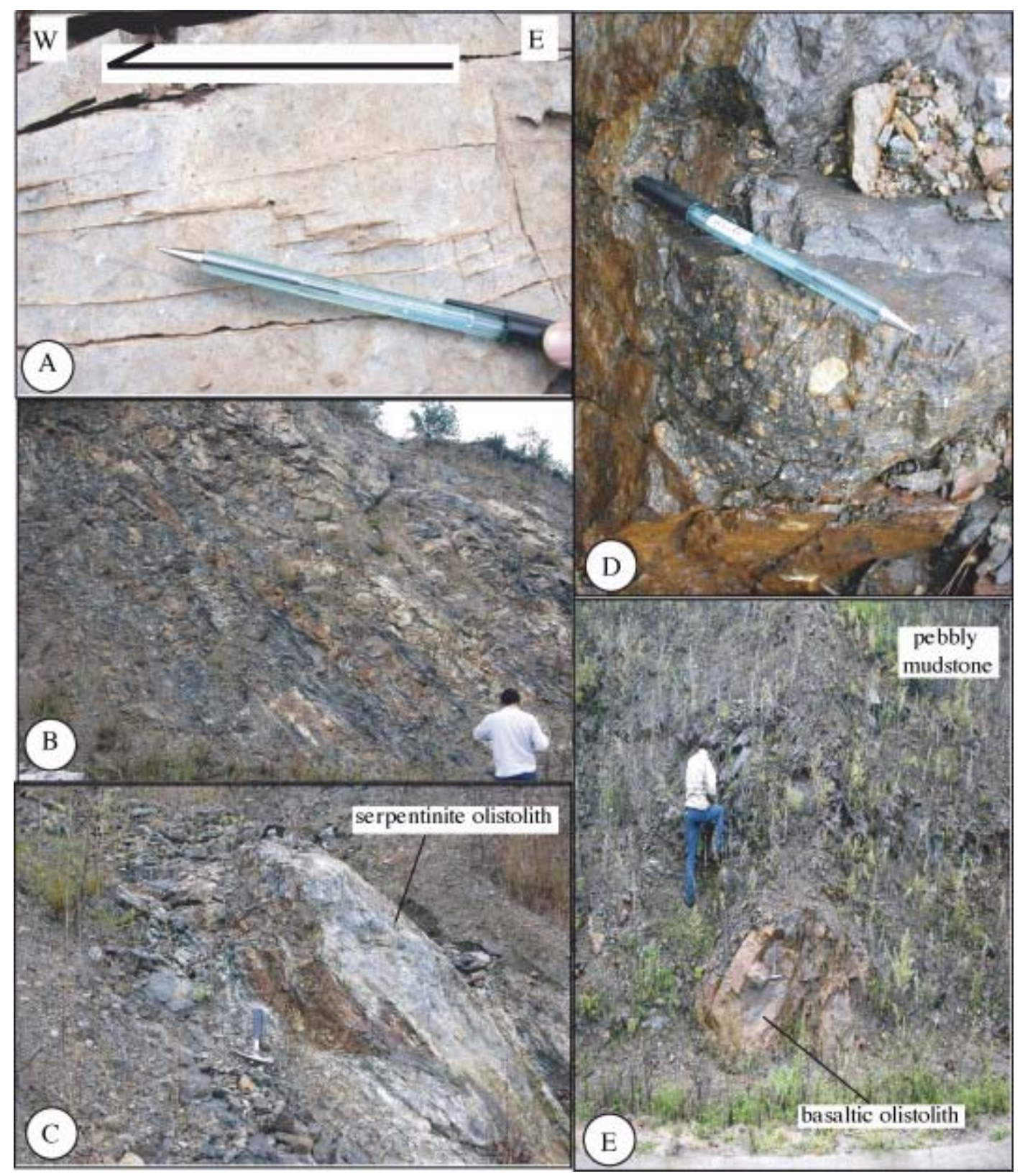

Fig. 2. Field pictures and microphotographs of the Central Jilin suture. A: flat-lying en-échelon tension gashes in Carboniferous limestone showing top-to-the-west brittle shearing, east of Panshi. B: sigma-type quartz showing top-to-the-west ductile shearing, west of Huadian. C: serpentinite olistolith included in a turbiditic matrix, southeast of Yongji. D: sample view of a pebbly mudstone with andesitic clasts, southeast of Yongji. E: block of mafic rock in a turbiditic matrix, west of Yongji.

Fig. 2. Photographies de terrain et de lames de la suture du Jilin central. A : fentes en échelon subhorizontales dans des calcaires carbonifères, indiquant un cisaillement fragile vers l'ouest, à l'est de Panshi. B : quartz sigmoïde indiquant un cisaillement vers l'ouest, à l'ouest de Huadian. C : olistolithe de serpentinite inclus dans une matrice turbiditique, au sud-est de Yongji. D : échantillon de pebbly mudstone avec des clastes andésitiques, au sud-est de Yongji. E : bloc de roche basique inclus dans une matrice turbiditique, à l'ouest de Yongji. 

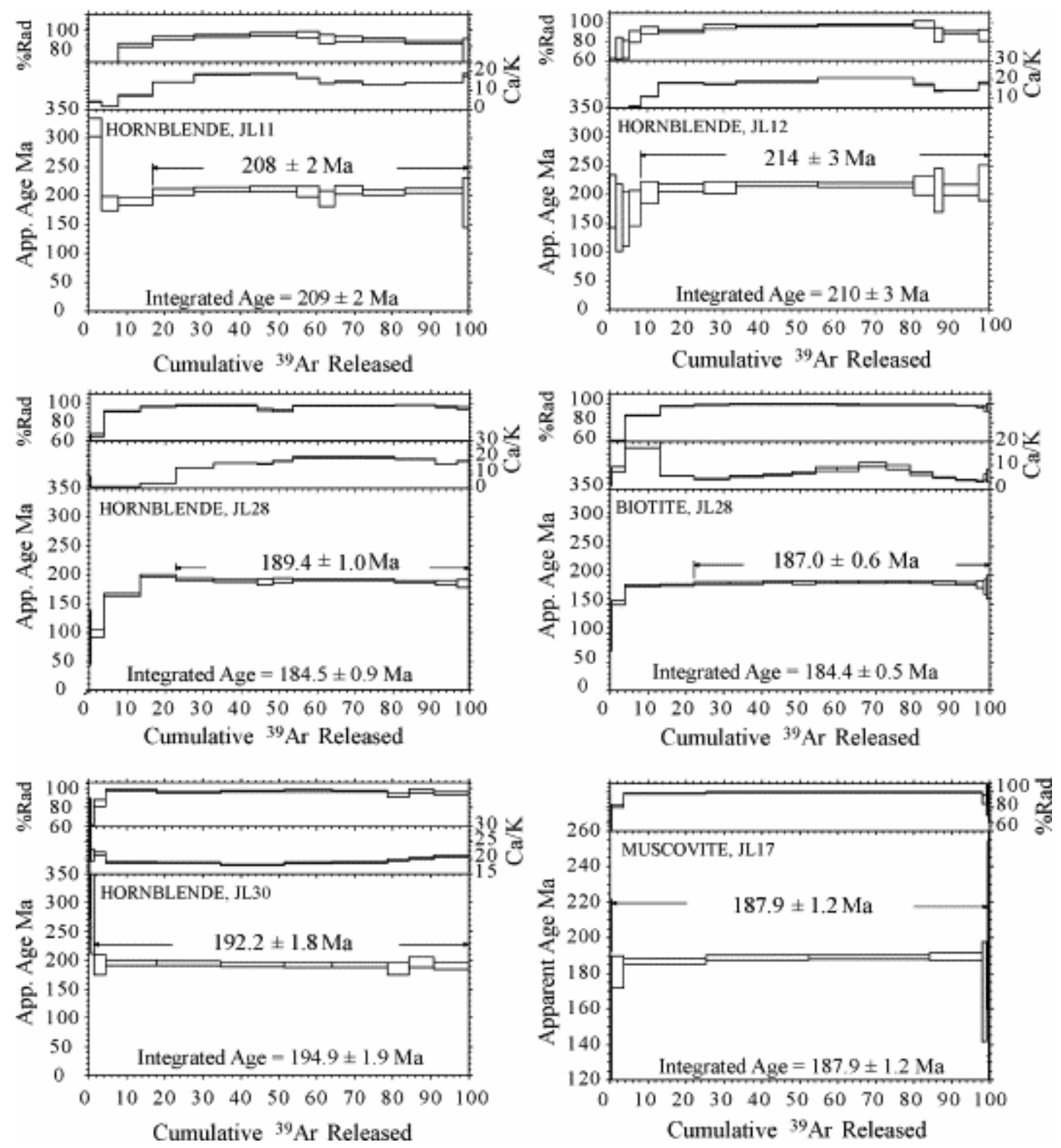

Fig. $3 .{ }^{40} \mathrm{Ar} /{ }^{39} \mathrm{Ar}$ spectra for hornblende, biotite, and muscovite from the Jilin suture. The sampling locations are given in Fig. 1.

Fig. 3. Spectres ${ }^{40} \mathrm{Ar} /{ }^{39} \mathrm{Ar}$ de hornblende, biotite et muscovite de la suture de Jilin. La localisation des échantillons est indiquée sur la Fig. 1 


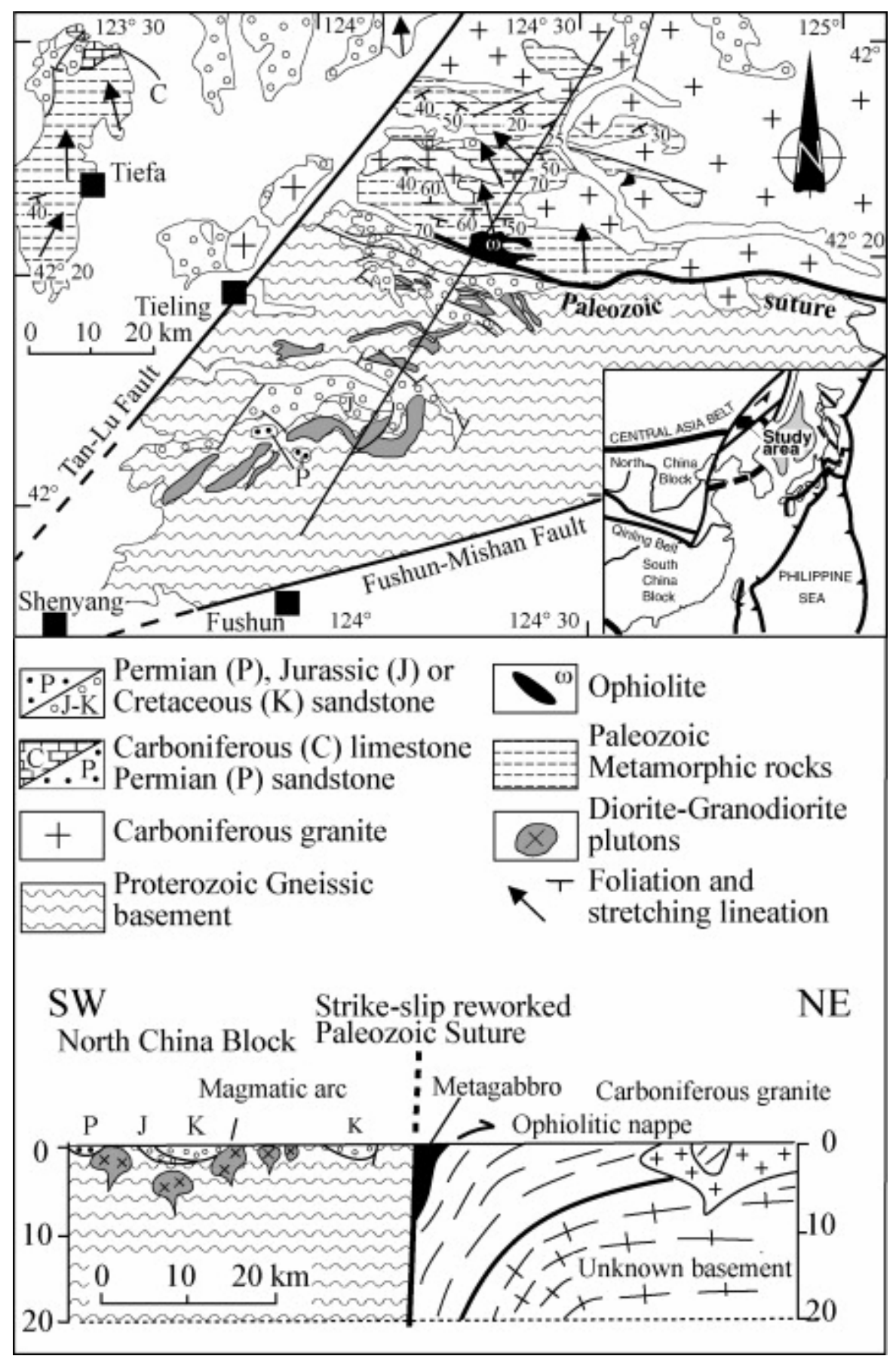

Fig. 4. Structural map and cross section of the Palaeozoic suture in the East Liaoning Province, near Tieling, adapted from [8] and completed by personal data. YYF: Yilan-Yitong fault, FMF: Fushun-Mishan fault, CAOB: Central Asia Orogenic Belt.

Fig. 4. Carte et coupe de la suture paléozoïque de l'Est Liaoning, près de Tieling, modifiées d'après [8], et complétées par nos données personnelles. YYF : faille Yilan-Yitong, FMF : faille Fushun-Mishan, CAOB : ceinture orogénique d'Asie centrale. 


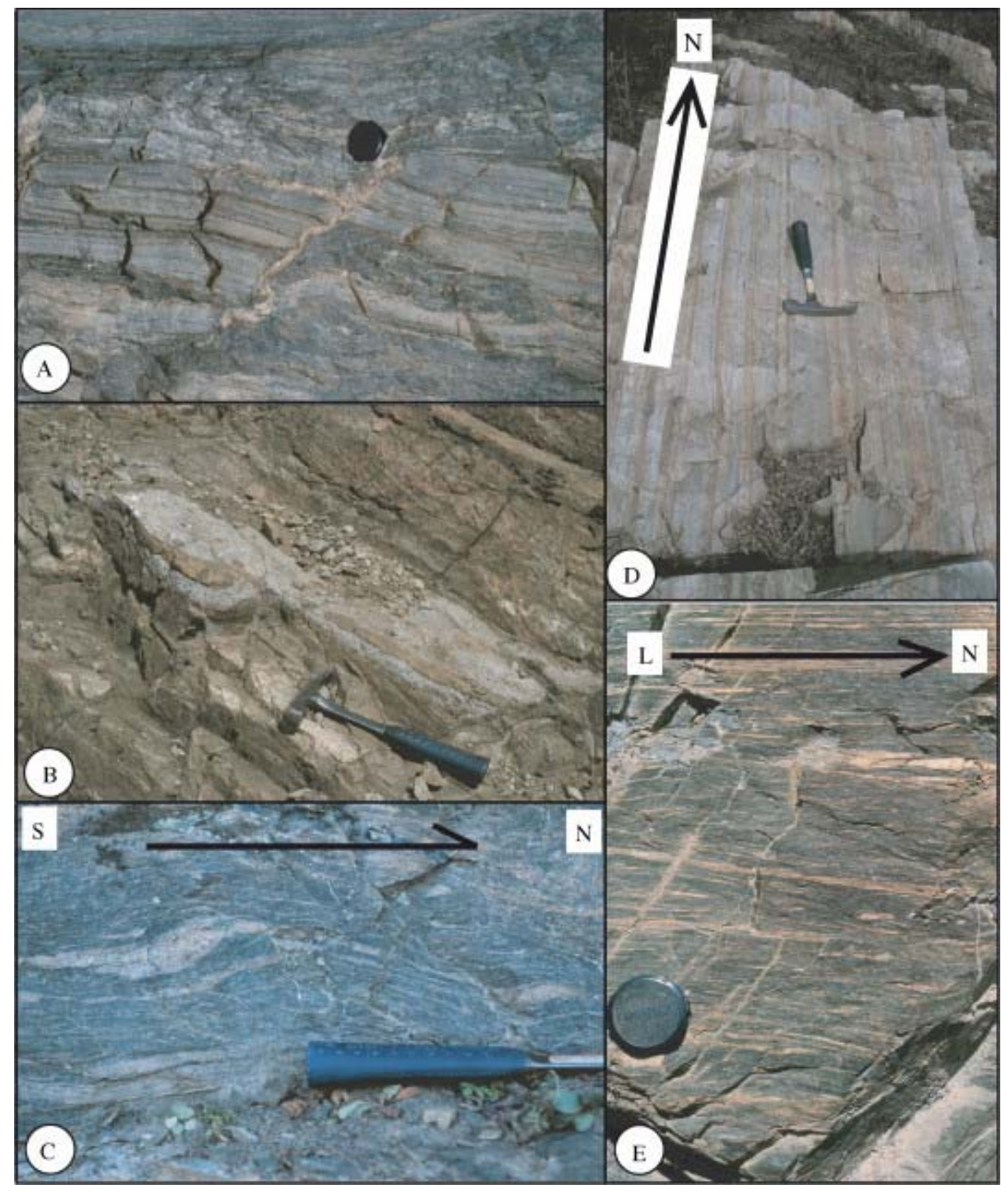

Fig. 5. Field pictures and microphotographs of the Liaoning suture, near Tieling. A: typical view of the greenish metasedimentary (pelite-grauwacke) matrix of the mafic rocks; B: sigmoidal chert lens indicating a top-to-thenorth shearing in the metamorphic rocks, northeast of Tieling; $\mathbf{C}$ : sigmoidal amphibole in the mylonitized metagabbro, indicating a top-to-the-north shearing; D: well-bedded white and red chert turned to vertical; E: foliated and lineated gneiss ( $X Y$ section).

Fig. 5. Photographies de terrain et de lames de la suture de Liaoning près de Tieling. $\mathbf{A}$ : vue typique des métasédiments verts (pélite-grauwacke) représentant la matrice des roches basiques ; $\mathbf{B}$ : lentille sigmoïde de chert indiquant un cisaillement vers le nord dans les roches métamorphiques, au nord-est de Tieling ; C : amphibole sigmoïde dans un métagabbro mylonitisé, indiquant un cisaillement vers le nord; $\mathbf{D}$ : radiolarite rubanée blanche et rouge verticalisée ; $\mathbf{E}$ : gneiss folié et linéé (section $X Y$ ). 


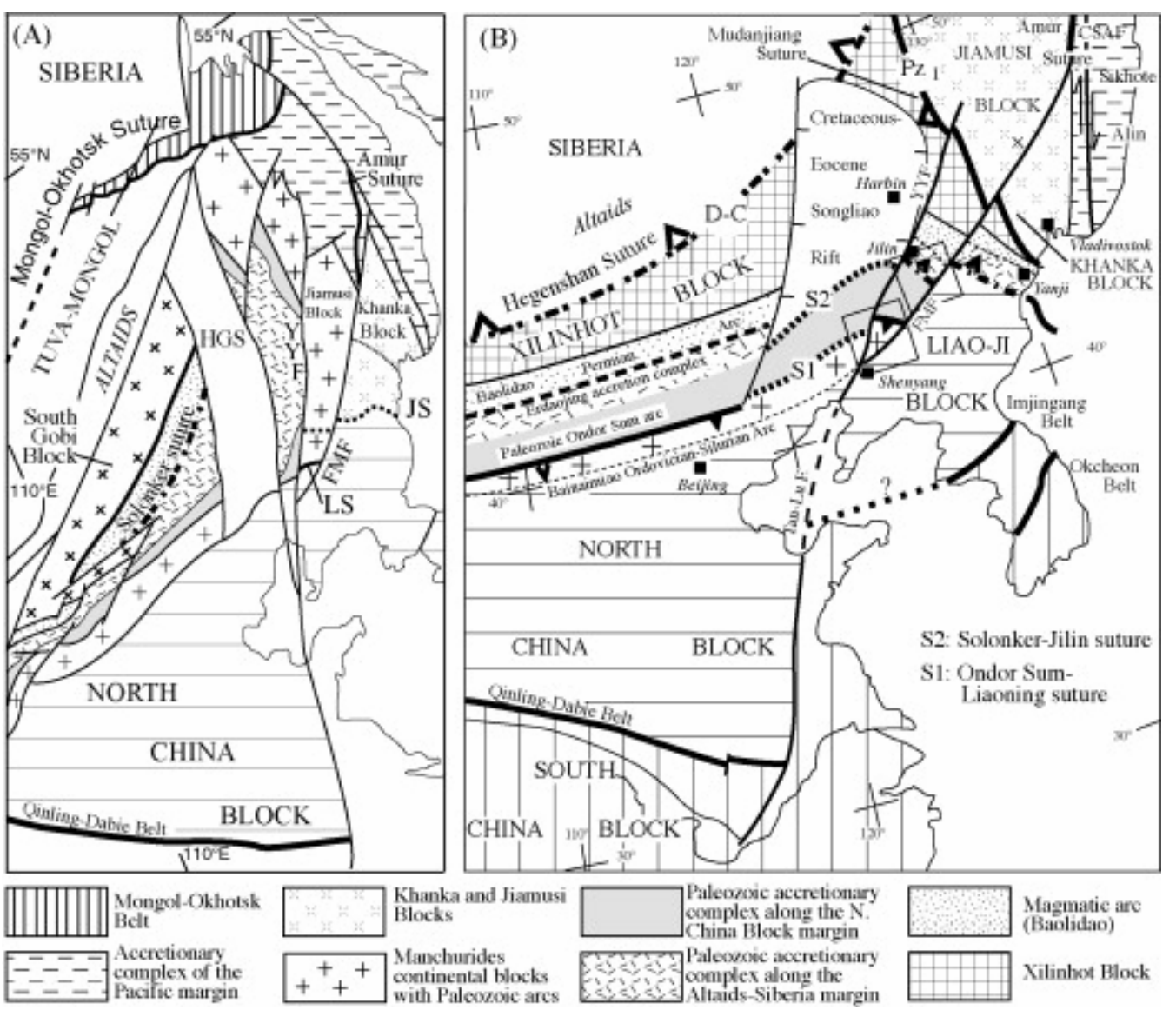

Fig. 6. Two possible tectonic maps of pre-Jurassic features in North China-Southeast Siberia. A: tectonic map simplified from [16]; note that the Northeast China sutures are not identified there and that the Khanka and Jiamusi Blocks are considered as two distinct microcontinents. B: correlation map between the Northeast China sutures described in this paper and those of Inner Mongolia according to [32]. S1 and S2 show the correlation between the Ondor Sum-Liaoning suture and the Solonker-Jilin suture, respectively. The Jiamusi and Khanka Blocks are interpreted as a single microcontinent separated from the Xilinhot Block by the Mudanjiang suture. (JS: Jiling suture, LS: Liaoning suture, HG: Hegenshan suture; FMF: Fushun-Mishan fault, YYF: Yilan-Yitong fault).

Fig. 6. Deux cartes des corrélations possibles entre les structures pré-Jurassiques en Chine du Nord et Sibérie du Sud-Est. A : carte tectonique simplifiée d'après [16] ; noter que les sutures de Chine du Nord-Est ne sont pas identifiées ici, les blocs de Khanka et Jiamusi étant considérés comme deux microcontinents distincts. B : carte de corrélation entre les sutures de Chine du Nord-Est décrites dans cet article et celles de Mongolie intérieure, d'après [32]. Les sutures S1 and S2 correspondent respectivement à celles d'Ondor Sum-Liaoning et de Solonker-Jilin. Les blocs de Jiamusi et Khanka sont interprétés comme un seul microcontinent, séparé du bloc de Xilinhot par la suture de Mudanjiang. (JS : Suture de Jiling ; LS : suture de Liaoning ; HG : suture de Hegenshan ; FMF : faille Fushun-Mishan ; YYF : faille Yilan-Yitong). 


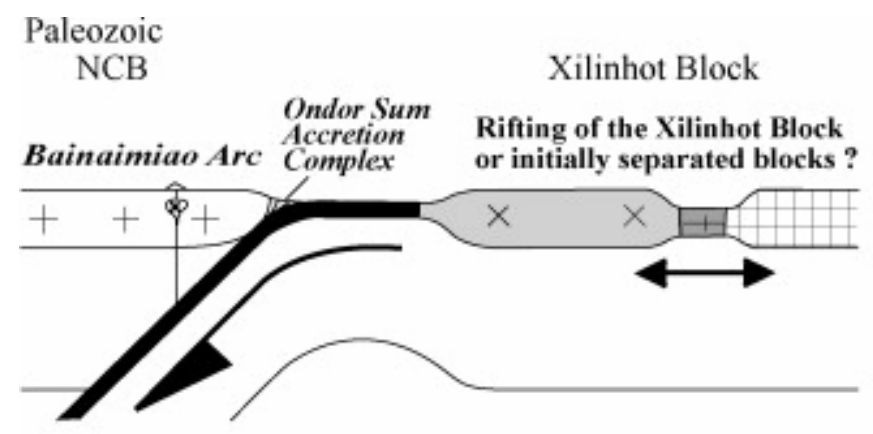

Late Carboniferous-Permian

Ondor Sum-Liaoning Suture
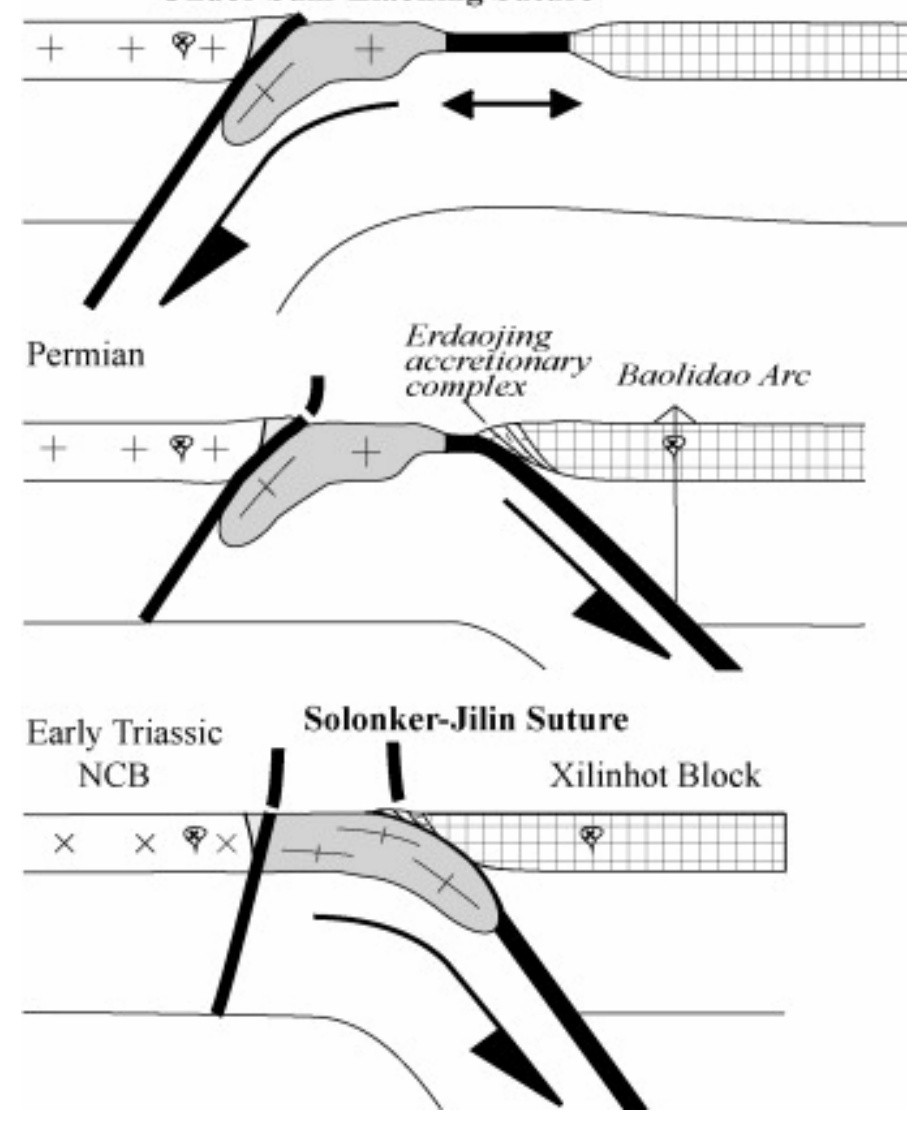

Fig. 7. Geodynamic evolution model for the eastern part of the CAOB, placing emphasis on the two successive collisions of microcontinents in the Late Carboniferous-Permian and the Late Permian-Early Triassic (see text for discussion).

Fig. 7. Modèle d'évolution géodynamique pour la partie orientale du CAOB, montrant les deux collisions successives de microcontinents au Carbonifère supérieur-Permien et au Permien supérieur-Trias inférieur (voir la discussion dans le texte). 